\title{
PENGARUH TEKNIK ROLE PLAYING DALAM BIMBINGAN KELOMPOK TERHADAP TOLERANSI PADA PESERTA DIDIK KELAS X SMK NEGERI 26 JAKARTA
}

\author{
Wirda Hanim ${ }^{1}$ \\ Aip Badrujaman² \\ Elsya Pratiwi ${ }^{3}$
}

\begin{abstract}
Abstrak
Penelitian eksperimen ini bertujuan untuk meningkatkan toleransi peserta didik kelas X SMK Negeri 26 Jakarta melalui teknik role playing dalam bimbingan kelompok. Populasi sebanyak 360 peserta didik. Sampel dalam penelitian ini adalah kelas X SMK Negeri 26 Jakarta yaitu 10 untuk kelompok eksperimen dan 10 untuk kelompok kontrol yang didapatkan dengan menggunakan teknik Purpossive sampling. Metode yang digunakan adalah eksperimen dengan desain kuasi eksperimen dalam bentuk pretest-posttest nonequivalent group design. Pengukuran pada penelitian ini menggunakan instrumen toleransi yang berjumlah 47 butir dengan realibilitas 0.745. Hasil pengujian hipotesis menggunakan Mann Whitney U-Test menunjukkan nilai Asymp. Sig sebesar 0.000 yang berarti nilai probabilitas lebih kecil dari nilai signifikansi $\alpha 0.05$, Sehingga $\mathrm{H}_{0}$ ditolak dan $\mathrm{H}_{1}$ diterima. Hasil penelitian menunjukan teknik role playing dalam bimbingan kelompok berpengaruh positif terhadap toleransi siswa kelas X SMK Negeri 26 Jakarta. Selanjutnya, guru BK dapat mengimplementasikan teknik role playing dalam bimbingan kelompok sebagai salah satu alternatif layanan untuk meningkatkan toleransi peserta didik di sekolah.
\end{abstract}

Kata Kunci: Role Playing, Bimbingan Kelompok, Toleransi

\begin{abstract}
This experimental research aims to increase the tolerance of students class X SMK Negeri 26 Jakarta through role playing techniques in group guidance. Populasi are 360 students. The sample is the students of class X SMK Negeri 26 Jakarta are 10 students for the experimental group and 10 students for the control group using Purpossive sampling technique. The method used is experiment with quasi experimental design in the form of pretest-posttest nonequivalent group design. Measurements in this study using a tolerance instrument consisting of 47 items with a realibility of 0.745 . The results of hypothesis testing using Mann Whitney U-Test shows the value of Asymp value. Sig of 0.000 which means the probability value is smaller than the significance value $\alpha 0.05$. So $H_{0}$ is rejected and $H_{1}$ accepted. The results showed role playing technique in the guidance of the group have a positive effect of tolerance of students of class X SMK Negeri 26 Jakarta. Furthermore, guidance and counseling teacher can implement role playing techniques in group guidance as an alternative service to increase tolerance of students in school
\end{abstract}

Keywords: Role Playing, Group Guidance, Tolerance

\footnotetext{
${ }^{1}$ Mahasiswa Program Studi Bimbingan dan Konseling FIP UNJ, aip_bj@yahoo.com

${ }^{2}$ Dosen Program Studi Bimbingan dan Konseling FIP UNJ, wirdahanim10@gmail.com

${ }^{3}$ Dosen Program Studi Bimbingan dan Konseling FIP UNJ, elsya.pratiwi.kuliah@gmail.com
} 


\section{PENDAHULUAN}

Toleransi termasuk kedalam salah satu karakter dalam Pendidikan Budaya dan Karakter Bangsa yang ingin dibangun pada generasi Indonesia. khususnya peserta didik di sekolah. Peserta didik yang memiliki nilai toleransi diharapkan akan menyadari bahwa setiap orang memiliki hak untuk dihomati, disayangi dan dihargai meskipun mungkin mereka memiliki perbedaan dengan diri mereka. Baik itu perbedaan pendapat, keyakinan, maupun perilaku (Borba, 2008).

Berdasarkan hasil wawancara dengan guru BK dan kepala SMK Negeri 26 Jakarta yang menjadi tempat penelitian, SMK Negeri 26 Jakarta merupakan sekolah yang menerapkan pendidikan karakter untuk peserta didik termasuk menanamkan nilai toleransi. Namun, Kepala Sekolah dan Guru BK menjelaskan bahwa masih terdapat beberapa permasalahan terkait karakter toleransi peserta didik yang masih terjadi di SMK Negeri 26 Jakarta. Terdapat perilaku-perilaku yang mengindikasikan peserta didik kurang memiliki karakter toleransi, khususnya pada kelas X. perilaku-perilaku intoleran yang ditunjukan yaitu, masih terdapat peserta didik yang saling ejek dengan sesama temannya. Hal-hal yang sering dijadikan bahan ejekan yaitu bentuk fisik, kemampuan akademik, dan status keluarga. Hal tersebut menyebabkan peserta didik yang diejek seringkali menarik diri dari pergaulan di kelas. Perilaku intoleran yang kedua yaitu ketika tidak menyukai cara mengajar seorang guru di kelas, peserta didik langsung menunjukan rasa tidak suka nya dengan cara menertawakan guru tersebut dan tidak memperhatikan selama guru tersebut mengajar di kelas. Perilaku intoleran yang ketiga yaitu peserta didik perempuan seringkali merasa tersisihkan dari pergaulan dikelas yang di dominasi peserta didik lakilaki. Perilaku intoleran yang ketiga yaitu terjadi beberapa kasus peserta didik laki-laki yang tampil di depan kelas untuk membaca puisi atau mengikuti lomba membaca puisi ditertawakan oleh temannya, karena menurut mereka membaca puisi lebih cocok untuk

Insight: Jurnal Bimbingan dan Konseling 6(2) dilakukan oleh perempuan.

Fenomena di atas menegaskan bahwa pendidikan karakter, khususnya toleransi, menjadi semakin mendesak untuk diterapkan. Selain itu, penamaman nilai toleransi penting diberikan kepada peserta didik SMK karena peserta didik lulusan SMK akan diarahkan dan dibekali kemampuan untuk bisa langsung memasuki dunia kerja dan dihadapkan pada persaingan yang ketat dengan calon pekerja lain nya, ketika bekerja, peserta didik akan bertemu dengan banyak orang yang berbeda baik itu atasan ataupun rekan kerja nya sendiri. Tentu, peserta didik harus bisa menyesuaikan diri dengan berbagai sikap yang ditunjukan oleh atasan dan rekan kerjanya dan mampu bekerja sama dengan orang-orang tersebut.

Toleransi merupakan salah satu nilai krusial yang harus ada ketika kita berhubungan dengan orang lain. Menerima dan menghormati perbedaan antara rekan kerja akan membuat kita mudah berbaur sehingga dapat tercapai produktivitas kerja yang baik. Lickona mempertegas peryataan di atas dengan mengatakan bahwa pemahaman toleransi sangat dibutuhkan karena pemuda saat ini akan berkontribusi dalam masyarakat yang memiliki latar belakang yang berbeda-beda (Lickona, 2012).

Berdasarkan penjelasan di atas, dapat diketahui pentingnya pendidikan karakter toleransi untuk diberikan kepada peserta didik SMK, khususnya SMKN 26 Jakarta, maka di perlukan suatu program khusus untuk membentuk karakter tersebut. Pada unit Bimbingan dan Konseling terdapat strategi dalam Bimbingan dan Konseling yang dapat diberikan dalam upaya membentuk karakter peserta didik yaitu bimbingan Bimbingan Kelompok. Menurut Sitti dan Hartinah, melalui Bimbingan Kelompok sikap-sikap positif peserta didik dapat dikembangkan, seperti sikap toleransi (Hartinah \& Sitti, 2009). Selain itu, pada usia remaja teman sebaya merupakan faktor yang paling mempengaruhi kehidupan remaja (Steinberg, 2002). Remaja cenderung akan lebih mudah belajar dengan teman sebaya 
daripada orang dewasa.

Guna mengoptimalkan pelaksanaan bimbingan kelompok untuk membentuk toleransi peserta didik, peneliti akan menggunakan teknik Role Playing yang merupakan salah satu teknikyang bisa dilakukan dalam setting Bimbingan Kelompok (Tatiek, 2001). Karakteristik remaja yang menyukai hal baru, tidak menyukai hal-ha yang monoton tentunya akan menjadi tantangan bagi guru BK untuk menciptakan dinamika kelompok yang lebih menyenangkan. Salah satu cara yang bisa digunakan untuk membuat dinamika kelompok menjadi lebih menyenangkan adalah teknik role playing. Menurut Jacob, untuk membuat remaja aktif dalam kegiatan kelompok, pembimbing harus merancang kegiatan yang aktif dan menarik, melalui teknik role playing akan membuat anggota lebih mudah terlibat aktif dalam kegiatan (Jacob, Mason, \& Harvill, 2006).

Selain itu, menurut kouchok cara yang tepat untuk mengajarkan toleransi pada remaja adalah dengan mencontohkan, memberi pemahaman, dan memberi pengalaman (Kouchok, 2005). Hal tersebut sesuai dengan perkembangan kognitif remaja yang sudah mampu untuk melihat simbol atau contoh kemudian analisis dan hipotesis dengan didiskusikan dan kemudian remaja mampu membuat keputusan atau mencari pemecahan masalah dan kemudian di uji terhadap realitas melalui pengalaman (Solso, Maclin, \& dkk, 2007). Oleh karena itu, teknik role playing dianggap tepat untuk meningkatkan toleransi remaja.

Pernyataan di atas, diperkuat oleh hasil Penelitian yang dilakukan oleh Agnestya Widyarati mendapatkan hasil bahwa proses pembelajaran IPS melalui metode Bermain Peran dapat meningkatkan sikap toleransi peserta didik Kelas XI SMA dari siklus I hanya memperoleh presentase 43,58\%, meningkat pada siklus II menjadi 92,30 \% (Widyarati, 2015).

Selain itu, penelitian yang dilakukan oleh Kiromim Baroroh mendapatkan hasil bahwa teknik Role Playing bisa meningkatkan berbagai karakter mahasiswa tingkat pertama, Hasil dari penelitian tersebut terdapat peningkatan karakter disiplin sebesar $10.9 \%$, kerja keras $7.4 \%$, kreatif $19.6 \%$, dan toleransi $18.9 \%$. Peningkatan tersebut dipengaruhi oleh berbagai faktor diantaranya proses role playing yang sangat menarik bagi peserta didik sehingga membuat siswa memiliki pengalaman yang bermakna (Baroroh, 2011).

\section{ACUAN TEORITIK}

\section{Toleransi}

Toleransi merupakan sebuah sikap yang memiliki kesetaraan dan tujuan bagi mereka yang memiliki pemikiran, ras, dan keyakinan yang berbeda-beda. Toleransi adalah sesuatu yang membuat dunia setara dari berbagai perbedaan (Lickona, 2012) Toleransi merupakan kebajikan moral yang berharga yang dapat mengurangi kebencian, kekerasan, dan kefanatikan. Melalui nilai toleransi, seseorang dapat memperlakukan orang lain secara baik, hormat, dan pengertian meskipun orang tersebut memiliki perbedaan dengan kita (Borba, 2008). Jadi, dengan memiliki sikap toleransi seseorang bisa menyadari bahwa semua orang memiliki hak yang sama untuk dihargai dan di sayangi mekipun pendapat dan keyakinannya berbeda dengan yang kita miliki.

\section{Aspek-Aspek Toleransi}

Michele Borba, menjelaskan bahwa toleransi memiliki dua aspek yaitu, aspek pertama yaitu rasa hormat: terhadap martabat manusia dan hak asasi semua orang, termasuk kebebasan hati nurani menentukan pilihan selama tidak mengganggu hak orang lain (Borba, 2008). Meskipun hati nurani kita tidak dapat menerima pilihan orang lain bahkan meyakinkan mereka bahwa itu salah, toleransi akan mencegah kita dari tindakan pemaksaan pendapat terhadap orang lain atau secara tidak adil membatasi kebebasan mereka. Toleransi dapat membuat kita dapat sepakat untuk tidak sependapat, bahkan dalam persoalan 
paling kontroversial sekalipun, hal tersebut membuat kita mampu menghadapi perbedaan sebesar apapun meski kita tidak berhenti memperdebatkan nya (Borba, 2008).

Aspek yang kedua yaitu toleransi menghargai keberagaman manusia, berbagai nilai positif, serta bermacam peran manusia yang memiliki latar belakang, suku agama, Negara, dan budaya yang berbeda (Borba, 2008). Ketika seseorang memiliki karakter toleransi maka diharapkan seseorang dapat belajar ketertarikan, kegunaan, dan kekayaan pemikiran dan kehidupan orang lain serta dapat menarik manfaat dari penemuan tersebut, baik dirumah, sekolah, maupun lingkungan masyarakat. Selain itu, dengan toleransi, diharapkan seseorang dapat mengerti perbedaan suku bangsa dari setiap manusia, mampu menyadari bahwa manusia itu unik, mampu melihat sisi baik setiap manusia.

\section{Faktor-Faktor yang Mempengaruhi Toleransi}

1. Tahap perkembangangan: tahap perkembangan seseorang berpengaruh terhadap bagaimana seeorang memahami perbedaan, apa arti perbedaan tersebut bagi dirinya, dan bagaimana ia menghadapi perbedaan tersebut. Tahapan perkembangan tersebut dapat dijadikan alasan mengapa seseorang memiliki toleransi atau tidak memiliki toleransi.

2. Jenis kepribadian: Beberapa jenis kepribadian biasanya membuat seseorang cenderung bersikap intoleran. Misalnya seseorang yang memiliki kepribadian egois, narsistik, dan paranoid.

3. Hirearki kebutuhan: seseorang cenderung akan bersikap sesuai dengan tingkat kebutuhannya sudah tercapai atau belum. Jika kebutuhan rasa aman atau kesejahteraan seseorang belum tercapai biasanya dia akan tertutup dan menjauh dari orang-orang tertentu yang dianggap mengancam.

4. Experience (pengalaman): pengalaman melakukan dan diperlakukan. Kemudian akan menjadi kebiasaan. pengalaman bisa didapatkan melalui metode pengajaran di sekolah maupun dirumah

5. Pemahaman: melalui pengajaran langsung mengenai toleransi yang diberikan orangtua dan guru disekolah

6. Imitasi: meniru yang dilakukan orangtua, teman, kerabat atau idola.

\section{Cara Mengajarkan Toleransi}

Menurut kouchok, berikut adalah beberapa prinsip dan panduan untuk mengembangkan dan menerapkan program mengenai nilai karakter khususnya toleransi (Kouchok, 2005): 1) Ajarkan Toleransi melalui contoh, 2) Ajarkan Toleransi melalui diskusi dan penjelasan 3) Ajarkan toleransi dengan menyediakan lingkungan belajar yang sesuai 4) Ajarkan toleransi melalui pengalaman 5) Ajarkan toleransi dalam bentuk 6) Ajarkan toleransi dengan melibatkan orangtua dan staff sekolah 7) Ajarkan toleransi melalui pada lingkungan yang menyenangkan

\section{Pengertian Bimbingan Kelompok}

Winkel mendefinisikan bimbingan kelompok sebagai sebuah proses layanan yang diberikan kepada lebih dari satu orang dalam waktu bersamaan (Winkel \& Hastuti, 2006), guna membantu mereka memperoleh pengetahuan dan keterampilan-keterampilan yang dapat diaplikasikan dalam membuat pilihan-pilihan, rencana-rencana, dan interpretasi-interpretasi yang diperlukan untuk penyesuaian diri yang baik (Winkel \& Hastuti, 2006). Sedangkan Djumhur dan Surya berpendapat bahwa bimbingan kelompok adalah suatu teknik yang dipergunakan untuk membantu peserta didik atau kelompok peserta didik dalam memecahkan masalahmasalah melalui kegiatan kelompok (Suradi \& Nursalim, 2002).

Prayitno mengemukakan pendapatnya mengenai bimbingan kelompok sebagai suatu kegiatan yang dilakukan oleh sekelompok orang dengan memanfaatkan dinamika kelompok, artinya semua orang yang menjadi 
anggota kelompok akan saling berinteraksi, bebas mengemukakan pendapat, dan saling bertukar fikiran mengenai informasi yang bermanfaat (Prayitno \& Amti, 2004).

\section{Manfaat Bimbingan Kelompok}

Hartinah memaparkan manfaat Bimbingan Kelompok sebagai berikut (Hartinah \& Sitti, 2009):

1. Peserta didik dapat mengenal dirinya melalui pergaulan bersama teman sebaya sehingga peserta didik mampu mengidentifikasi perilaku dan sikap yang dimiliki oleh dirinya, apakah sudah baik atau belum.

2. Dalam interaksi sosial sikap dan sifat peserta didik akan terbentuk menjadi baik dan positif, misalnya mempunyai rasa toleransi, menghargai pendapat orang lain, kerjasama yang baik, tanggung jawab, disiplin, kreatif, saling mempercayai dan sebagainya

3. Dapat mengurangi rasa malu, agresif, penakut, emosional, pemarah, dan lain sebagainya yang dialami peserta didik

4. Dapat mengurangi ketegangan emosional, konflik, frustasi yang dialami peserta didik.

5. Dapat mendorong peserta didik lebih gairah di dalam melaksanakan tugas, suka berkorban kepada kepentingan orang lain, suka menolong, bertindak teliti, dan hatihati

\section{Tahapan Bimbingan Kelompok}

Pada pelaksanaannya, Bimbingan kelompok memiliki beberapa tahapan yang harus dilalui. Peniliti akan menggunakan bentuk bimbingan kelompok didasarkan pada Education Group menurut Jacobs, Mason dan Harvill yang terdiri dari 3 (tiga) tahapan (Jacob, Mason, \& Harvill, 2006). Tahapan-tahapannya yaitu: Beginning stage, Middle stage. dan Clsoing stage.

\section{Teknik dalam Bimbingan Kelompok}

Menurut Thompson dan William, terdapat contoh-contoh kegiatan yang bisa dilakukan dalam bimbingan kelomok yaitu diskusi dalam kelas, brainstorming, melakukan permainan, menyelesaikan latihan, tugas dan/ atau lembar kerja, deskripsi diri, Role Playing dan mengarang kreatif (Winkel \& Hastuti, 2006). Sedangkan menurut Romlah terdapat beberapa teknik yang biasa di gunakan dalam bimbingan kelompok yaitu: pemberian informasi atau ekspositori, diskusi kelompok, pemecahan masalah (problem solving), penciptaan suasana kekeluargaan (homeroom), permainan peran (Role Playing), karyawisata, dan permainan simulasi (Tatiek, 2001).

\section{Pengertian Teknik Role Playing}

Joyce menyatakan bahwa metode Role Playing merupakan metode pembelajaran yang berasal dari dimensi individu dan sosial. Melalui metoode Role Playing peserta didik dapat secara bersama-sama mengemukakan perasaan, tingkah laku, nilai dan strategi pemecahan masalah (Joyce, Weil, \& Calhoun, 2009).

\section{Kelebihan Teknik Role Playing}

Teknik Role Playing memiliki beberapa kelebihan sebagai metode pembelajaran untuk mengembangkan potensi peserta didik. berikut kelebihan teknik Role Playing:

1. Dapat memberikan kesan yang kuat dan bertahan lama dalam ingatan peserta didik

2. Peserta didik akan lebih mudah memahami konsep yang diajarkan.

3. Membantu peserta didik merasakan lebih dekat dan lebih dalam mengenai materi yang sedang dipelajari' dengan cara terjun langsung untuk memerankan sesuatu yang akan dibahas.

4. Membangkitkan gairah dan optimisme dalam diri peserta didik dan menumbuhkan kebersamaan (Djamarah \& Zain, 2013).

5. Selanjutnya, kelebihan dari teknik ini menurut Joyce dan Well, yakni dapat menampilkan perasaan dan keyakinan dalam menghadapi berbagai macam dilema atau masalah, mendapatkan pelajaran mengenai empati dan bersedia mempelajari dan mengeksplorasi materi yang sensitif 
6. Dan tentunya, membantu peserta didik berempati, memahami serta menghargai orang lain yang memiliki beragam pendapat serta perilaku yang berbeda (Joyce, Weil, \& Calhoun, 2009).

\section{Tahapan Tenik Role Playing}

Menurut Sheftels dalam (Joyce, Weil, \& Calhoun, 2009) Berikut penjelasan lebih lanjut mengenai tahapan teknik Role Playing:

1. Menghangatkan situasi kelas. Peneliti menciptakan suasana yang kondusif dan menyenangkan dalam kelompok. Peneliti mulai membahas pengantar topik. Topik tersebut diilustrasikan kedalam contoh pada kehidupan sehari-sehari. Hal tersebut dilakukan sampai pesrta didik memahami mengenai situasi yang akan diperankan.

2. Memilih partisipan Peneliti memilih pemain peran dengan karakter yang berbeda-beda, sesuai dengan peran yang akan dimainkan. Pemilihan pemeran bisa dilakukan dengan cara meminta sukarelawan atau dipilih berdasarkan undian.

3. Mempersiapkan pentas Peneliti mempersiapkan pentas, seperti menjelaskan peran-peran yang akan diperankan oleh peserta didik peserta didik akan mempersiapkan alur pementasan sesuai dengan situasi yang telah peneliti jelaskan, namun tidak perlu menyiapkan dialog khusus. Selain itu peneliti juga memberikan kesempatan bagi peserta didik tersebut untuk mendiskusikan perkiraan adegan yang akan diperankan

4. Menyiapkan pengamat Pengamat dalam hal ini yaitu para para peserta didik lain yang tidak memainkan peran. Kegiatan ini dilakukan dengan mempersiapkan hal-hal yang harus diamati dan diperhatikan untuk didiskusikan pada akhir Role Playing.

5. Memerankan Peserta didik mulai memainkan peranannya masing-masing secara spontan dan melakukan improvasi sesuai situasi yang telah disampakan oleh peneliti.

6. Diskusi dan evaluasi. Peneliti dan peserta didik mendiskusikan dan mengevaluasi kegiatan yang sudah diperankan odan apa saja yang harus dikembangkan untuk pemeranan selanjutnya

7. Memerankan kembali, diskusi dan evaluasi. Tahap ini dilaksanakan apabila pada tahap pemeranan pertama masih ada peserta didik yang belum memahami secara utuh kegiatan yang sudah diperankan maka perlu dilakukan pemeranan kembali lalu diskusi dan evaluasi

8. Berbagi dan mengembangkan pengalaman. Peneliti dan anggota saling berbagi dan mengembangkan pengalaman. Kegiatan ini dilakukan dengan menghubungkan situasi permasalahan dengan pengalaman yang sebenarnya terjadi

\section{METODE PENELITIAN}

Penelitian ini bertujuan untuk mengetahui tentang profil karakter toleransi peserta didik kelas X di SMK Negeri 26 Jakarta dan Pengaruh bimbingan kelompok dengan teknik Role Playing terhadap peningkatan toleransi pada peserta didik kelas X di SMKN 26 Jakarta Penelitian ini di laksanakan di SMK Negeri 26 Jakarta. Waktu yang digunakan dalam penelitian ini dimulai dari bulan Juli - Agustus 2017. Metode penelitian yang digunakan dalam penelitan ini adalah metode Eksperimen yang dimaksudkan untuk mengetahui ada tidaknya akibat dari "sesuatu" yang diperlakukan kepada subjek penelitian (Arikunto, 2007).

Desain ekperimen yang digunakan dalam penelitian ini adalah kuasi eksperimen dalam bentuk pretest-posttes nonequivalent group design. Oleh sebab itu, penelitian ini akan melibatkan kelompok eksperimen sebagai kelompok yang akan mendapatkan perlakuan dan kelompok kontrol yang tidak mendapatkan perlakuan serta Kedua kelompok akan mendapatkan pretest dan posttest (Heppner, Wampold, \& Kivlighan, Jr., 2008)

Populasi dalam penelitian ini adalah peserta didik kelas X SMK Negeri 26 Jakarta yang memiliki yaitu sebanyak 360 peserta didik. Teknik sampling yang peneliti gunakan dalam penellitian ini adalah teknik purposive 
sampling. Peneliti memilih peserta didik kelas $\mathrm{X}$ SMK Negeri 26 Jakarta yang toleransi nya lebih rendah daripada yang lain. Peneliti memilih 20 orang peserta didik yang termasuk kedalam kategori sedang dan rendah. Kemudian peserta didik yang terpilih dibagi menjadi dua kelompok.

Penelitian dilakukan selama 9 pertemuan yang terdiri dari pretest, kegiatan pra bimbingan kelompok, 6 sesi bimbingan kelompok dengan teknik role playing, dan diakhiri dengan posttest.

Pada penelitian ini, pengukuran keterampilan toleransi peserta didik dilakukan dengan menggunakan instrumen yang dikembangkan peneliti yang berdasarkan teori Michele borba mengenai toleransi yang mempunyai dua aspek.

Pengaruh eksperimen terhadap sampel penelitian diketahui melalui pengolahan data dan analisis data menggunakan Mann Whitney $U$ Test dengan menggunakan bantuan aplikasi SPSS versi16.0. Hipotesis dalam penelitian ini diuji pada taraf signifikansi $\alpha=0,05$ atau dengan tingkat kesalahan sebesar 5\%.

\section{HASIL PENELITIAN}

\section{Hasil Data Toleransi Keseluruhan}

Berdasarkan hasil pretest-posttest yang dilakukan pada kelompok eksperimen dan kelompok kontrol dengan masing-masing terdiri dari 10 peserta didik kelas X SMKN 26 Jakarta, didapatkan hasil sebagai berikut:

Tabel.1 Data Pretest dan Posttest Toleransi

\begin{tabular}{ccccc}
\hline Kel. & $\mathrm{K}$ & $\begin{array}{c}\text { Rentang } \\
\text { skor }\end{array}$ & $\begin{array}{c}\text { Frek. } \\
\text { pretest }\end{array}$ & $\begin{array}{c}\text { Frek. } \\
\text { Posttest }\end{array}$ \\
\hline Eks. & $\mathrm{T}$ & $>165$ & 0 & 8 \\
& $\mathrm{~S}$ & $137-165$ & 6 & 2 \\
& $\mathrm{R}$ & $<137$ & 4 & 0 \\
Kont. & $\mathrm{T}$ & $>165$ & 0 & 0 \\
& $\mathrm{~S}$ & $138-164$ & 6 & 4 \\
& $\mathrm{R}$ & $<137$ & 4 & 6 \\
\hline
\end{tabular}
Keterangan:
K: Kategori
S: Sedang
$\mathrm{T}$ : Tinggi
R: Rendah

Berdasarkan hasil pretest dan posttest pada kedua kelompok yaitu kelompok eksperimen dan kelompok kontrol terdapat perubahan skor yang terjadi. Pada kelompok eksperimen, pada hasil pretest menunjukan 4 peserta didik berada pada kategori rendah yaitu YR, MD, FA dan AB dan 6 peserta didik berada pada kategori sedang yaitu AN, SP, AA, AJ, JL, dan NA. Rata-rata skor sebelum diberi perlakuan yaitu 134.9 atau $71.75 \%$. sedangkan setelah diberi perlakuan seluruh peserta didik mengalami peningkatan yaitu 6 orang peserta didik yang berada pada ketegori sedang meningkat menjadi kategori tinggi yaitu AN, SP, AA, AJ, JL, dan NA. 2 orang peserta didik yang berada pada kategori rendah meningkat menjadi kategori tinggi yaitu MD dan YR, dan 2 orang lainnya yang berada pada pada kategori rendah meningkat menjadi kategori sedang yaitu $\mathrm{AB}$ dan $\mathrm{FA}$ sehingga rata-rata perolehan skor meningkat menjadi 92.02. Maka gain skor pretest dan posttest kelompok eksperimen adalah 20.27 (Lihat tabel 1, 2, dan 4).

Sedangkan pada kelompok kontrol, pada hasil pretest menunjukan 4 peserta didik berada pada kategori rendah dan 6 peserta didik berada pada kategori sedang. Rata-rata skor sebelum diberi perlakuan yaitu 136.4. setelah setelah diberi perlakuan 6 orang tetap berada pada kategori sedang. 2 orang menurun dari kategori sedang menjadi rendah, dan 2 orang tetap pada kategori rendah. Rata-rata skor pada kelompok kontrol hanya meningkat 0.1 menjadi 136.5.

\section{Hasil Data Toleransi Per Aspek}

Berdasarkan hasil data penelitian diketahui bahwa pada kelompok eksperimen setiap individu mengalami peningkatan pada Aspek 1 maupun Aspek 2. Pada aspek 1 ratarata skor yang diperoleh saat pretest adalah 
65.6, sedangkan rata-rata skor yang diperoleh saat posstest adalah 85.6. Pada aspek 2 rata-rata skor yang diperoleh saat pretest adalah 70.8 dan rata-rata skor yang diperoleh saat posttest adalag 84.8 (Liht tabel 5). Sedangkan pada kelompok kontrol, kebanyakan peserta didik mengalami penurunan di setiap aspek toleransi pada pesrta didik meskipun ada beberapa peserta didik yang mengalami peningkatan. Pada aspek 1 rata-rata skor yang diperoleh saat pretest adalah 68.3. sedangkan rata skor yang diperoleh saat posstest adalah 67.1. Pada Aspek 2 rata-rata skor yang diperoleh saat pretest adalah 68.7 dan rata-rata skor yang diperoleh saat posttest adalag 67.5. (Lihat tabel 6)

\section{Pengujian Hipotesis}

Hasil pengujian Hipotsis menggunakan SPSS, nilai Asymp. Sig sebesar 0.000 yang berarti nilai probabilitas lebih kecil dari nilai signifikansi $\alpha 0.05$. Dengan demikian dapat disimpulkan bahwa $\mathrm{H}_{0}$ ditolak dan $\mathrm{H}_{1}$ diterima, yaitu terjadi peningkatan toleransi yang signifikan pada kelompok eksperimen setelah diberikan perlakuan. Maka dapat disimpulkan bahwa, terdapat pengaruh teknik role playing dalam bimbingan kelompok terhadap toleransi siswa kelas X SMK Negeri 26 Jakarta.

\section{PEMBAHASAN}

Terdapat beberapa faktor yang menyebabkan teknik role playing dalam bimbingan kelompok berpengaruh terhadap peningkatan toleransi siswa. faktor pertama yaitu Karena, menurut Steinberg pada usia remaja teman sebaya merupakan faktor yang paling mempengaruhi kehidupan remaja, dengan demikian Remaja cenderung akan lebih mudah belajar mengembangkan sikap positif, salah satunya sikap bertoleransi (Steinberg, 2002). Hal tersebut sejalan dengan tujuan Bimbingan Kelompok yang dijelaskan oleh Prayitno, yaitu Bimbingan kelompok bertujuan untuk melatih peserta didik agar memiliki berbagai keterampilan sosial, mampu memiliki rasa tenggang rasa, dan membantu peserta didik mengenali dan memahami hubungannya dengan orang lain (Prayitno \& Amti, 2004).
Faktor yang kedua adalah Teknik Role playing merupakan teknik pembelajaran yang membuat menarik peserta didik untuk ikut serta secara aktif dalam pembelajaran, selain itu Role playing merupakan teknik pembelajaran yang menyenangkan untuk peserta didik di semua umur. Terlebih peserta didik dapat belajar melihat segala situasi dari berbagai sudut pandang, termasuk sudut pandang orang lain (Lickona, 2012).

Faktor ketiga yaitu karena, teknik role playing merupakan teknik yang tidak hanya menjelaskan mengenai toleransi tetapi membuat peserta didik ikut secara aktif dalam mempraktekan apa yang sedang dibahas. Hal tersebut sesuai dengan cara-cara untuk mengajarkan toleransi menurut kouchok, yaitu Ajarkan toleransi melalui pengalaman (Kouchok, 2005). Nilai dipelajari dengan melakukan langsung tidak hanya memberi tahu dan menjelaskan. Oleh karena itu, peserta didik tidak hanya sekedar tahu melainkan memiliki perngalaman yang bermakna dan akan diingat dan dharapkan akan menjadi kebiasaan. Hal tersebut sesuai dengan proses belajar yang bisa dilakukan remaja yaitu diawali dengan melihat simbol atau contoh kemudian analisis dan hipotesis dengan di diskusikan dan kemudian remaja mampu membuat keputusan atau mencari pemecahan masalah dan kemudian di uji terhadap realitas melalui pengalaman (Solso, Maclin, \& dkk, 2007).

Faktor ke empat, melalui kegiatan role playing dalam bimbingan kelompok, peserta didik akan menghayati peran dan memahami perasaan orang lain sehingga peserta didik lebih bisa menghargai orang lain dan lebih mudah menerima perbedaan yang ada. Hal tersebut sesuai dengan kelebihan teknik role playing yaitu dapat membantu peserta didik berempati, memahami serta menghargai orang lain yang memiliki beragam pendapat serta perilaku yang berbeda. 


\section{KESIMPULAN, SARAN, DAN IMPLIKASI}

\section{Kesimpulan}

Setelah semua tahap dalam penelitian dilakukan; dapat disimpulkan bahwa:

1. Toleransi peserta didik sebelum mendapat perlakuan dengan teknik role playing terdapat 6 anggota yang berada pada kategori sedang dan 4 anggota yang berada pada kategori rendah. Setelah diberikan perlakuan roleplaying 6 orang pada kategori sedang meningkat menjadi kategori tinggi. 2 orang pada kategori rendah meningkat menjadi kategori sedang dan 2 orang lainnya yang berada pada kategori rendah meningkat menjadi kategori tinggi. Sehingga Rata-rata skor yang diperoleh pada pretest adalah 134.9 atau $71.75 \%$ dan rata-rata skor yang diperoleh pada posttest adalah 173 atau $92.02 \%$. Sehingga dapat diketahui rata-rata gain skor kelompok eksperimen sebesar 20.07 yang lebih tinggi dibandingkan dengan gain score kelompok kontrol yang hanya 0.05 . Berdasarkan penjelasan tersebut dapat disimpulkan peningkatan yang signifikan terjadi pada kelompok eskperimen, yaitu kelompok yang mendapat perlakuan dengan teknik role playing.

2. Berdasarkan hasil pengujian hipotesis dengan menggunakan teknik Mann Whitney $U$ Test, diperoleh hasil nilai asymp. Sig $=$ 0,000 . Hipotesis penelitian diuji pada taraf signifikansi $\alpha=0.05$ atau dengan tingkat kesalahan $5 \%$, maka Nilai Asymp. Sig = $0,000<$ nilai signifikansi $\alpha=0.05$, maka dapat disimpulkan bahwa $\mathrm{H}_{0}$ ditolak dan $\mathrm{H}_{1}$ diterima, ini mengartikan bahwa terjadi teknik role playing dalam bimbingan kelompok berpengaruh terhadap toleransi peserta didik.

\section{Implikasi}

Berdasarkan penelitian yang telah dilakukan, teknik role playing dalam bimbingan kelompok merupakan salah satu bentuk alternatif penanganan yang dapat diterapkan untuk meningkatkan toleransi peserta didk. Hal ini dibuktikan dengan hasil post test yang mengalami peningkatan dibandingan dengan hasil pre-test. Teknik role playing dalam bimbingan kelompok membuat memahami makna dari perbedaan dan bagaimana cara menyikapi perbedaan-perbedaan tersebut. Selain itu, teknik role play membuat peserta didik memiliki pengalaman baru dalam melakukan toleransi yang bisa digunakan dan dikembangkan di masa depan. Pengalaman tersebut diharapkan dapat memberikan kesan yang kuat pada peserta didik sehingga perilaku toleransi akan menjadi kebiasaan yang tertanam dalam diri peserta didik.

\section{Saran}

Saran-saran yang dapat menjadi pertimbangan berdasarkan hasil penelitian ini adalah:

1. Guru bimbingan dan konseling di sekolah disarankan untuk tetap memantau perkembangan peserta didik yang menjadi responden penelitian setelah mengikuti layanan bimbingan kelompok dengan teknik role playing. Khususnya perkembangan toleransi peserta didik.

2. Guru bimbingan dan konseling di sekolah disarankan menggunakan teknik role playing, sebagai salah satu alternatif dalam menangani peserta didik yang mengalami masalah terkait toleransi.

3. Bagi mahasiswa penelitian ini dapat dijadikan sebagai bahan bacaan yang berhubungan dengan kegiatan bimbingan, khususnya toleransi, bimbingan kelompok dan role playing.

4. Bagi peneliti selanjutnya yang akan meneliti dengan menggunakan teknik role playing diharapkan untuk membuat perencanaan yang desain yang lebih komperhensif dan matang.

\section{DAFTAR PUSTAKA}

Arikunto, S. (2007). Manajemen penelitian. Jakarta: Rineka Cipta. 
Baroroh, K. (2011). Upaya meningkatkan nilainilai karakter peserta didik melalui penerapan metode role playing. Jurnal Ekonomi \& Pendidikan, 1-15.

Borba, M. (2008). Membangun Kecerdasan Moral. (L. Jusuf, Trans.) Jakarta: Gramedia Pustaka Utama.

Djamarah, S. B., \& Zain, A. (2013). Strategi belajar mengajar. Jakarta: PT Rineka Cipta.

Hartinah, M., \& Sitti, D. H. (2009). Konsep dasar bimbingan kelompok. Bandung: PT Refika Aditama.

Heppner, P. P., Wampold, B. E., \& Kivlighan, Jr., D. M. (2008). Research design in counseling. USA: Thomson Brooks/ Cole.

Jacob, E., Mason, L. R., \& Harvill, L. R. (2006). Group counseling strategies and skills (5th ed.). Thomson: Belmont.

Jalal, F., Ramly, M., \& Harianti, D. (2016). Konsep dan Pedoman Penguatan Pendidikan Karakter. Jakarta: Kementrian Pendidikan dan Kebudayaan Republik Indonesia.

Joyce, B., Weil, M., \& Calhoun, E. (2009). Model-model pengajaran. $\left(8_{\text {th }}\right.$ ed.). (A. Fawaid, \& A. Mirza, Trans.) Yogyakarta: Pustaka Belajar.

Kouchok, K. H. (2005). How to teach and how not to teach tolerance. Istanbul: Center For Values Education, Istanbul.

Lickona, T. (2012). Mendidik untuk membentuk karakter: Bagaimana sekolah dapat memberikan pendidikan tentang sikap hormat dan tanggung jawab. (J. A. Wamaungo, Trans.) Jakarta: PT Bumi Aksara.

Prayitno, \& Amti, E. (2004). Dasar-dasar bimbingan dan konseling. Jakarta: Rineka Cipta.
Solso, R. L., Maclin, O. H., \& dkk. (2007). Psikologi kognitif. (M. Rahardianto, \& K. Batuadji, Trans.) Jakarta: Gelora Aksara Pratama.

Steinberg, L. (2002). Adolescence. New York: McGraw Hill Inc.

Suradi, M., \& Nursalim. (2002). Layanan bimbingan dan konseling. Semarang: Unes University Press.

Tatiek, R. (2001). Teori dan praktek bimbingan kelompok. Malang: UNM.

Widyarati, A. (2015). Upaya meningkatkan sikap toleransi melalui metode bermain peran dalam pembelajaran IPS pada siswa kelas XI SMA di jakarta timur. Jakarta: Universitas Negeri Jakarta.

Winkel, \& Hastuti, S. (2006). Bimbingan dan konseling di institusi pendidikan. Yogyakarta: Media Abadi. 
Lampiran Tabel

Tabel 1. Data Capaian Skor Toleransi

\begin{tabular}{|c|c|c|c|c|c|c|c|c|c|c|}
\hline \multirow[t]{2}{*}{ Kel } & \multirow{2}{*}{$\begin{array}{l}\text { Skor } \\
\text { ideal }\end{array}$} & \multirow[t]{2}{*}{ Nama } & \multirow[t]{2}{*}{ JK } & \multicolumn{3}{|c|}{ Skor } & \multicolumn{4}{|c|}{ Skor } \\
\hline & & & & Pretest & $\%$ & Kategori & Posttest & Kategori & $\%$ & $\begin{array}{l}\text { Gain } \\
\text { Skor }\end{array}$ \\
\hline \multirow{10}{*}{ 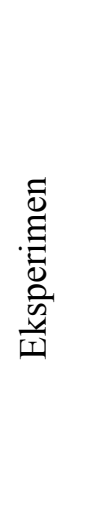 } & \multirow{10}{*}{188} & AN & $\mathrm{L}$ & 137 & 72.87 & Sedang & 179 & Tinggi & 95.21 & 22.34 \\
\hline & & $\mathrm{AB}$ & $\mathrm{L}$ & 135 & 71.80 & Rendah & 157 & Sedang & 83.51 & 10.63 \\
\hline & & AJ & $\mathrm{P}$ & 137 & 72.87 & Sedang & 174 & Tinggi & 92.55 & 19.68 \\
\hline & & $\mathrm{JL}$ & $\mathrm{P}$ & 137 & 72.87 & Sedang & 176 & Tinggi & 93.61 & 20.74 \\
\hline & & AA & $\mathrm{P}$ & 137 & 72.87 & Sedang & 179 & Tinggi & 95.21 & 22.34 \\
\hline & & MD & $\mathrm{L}$ & 129 & 68.61 & Rendah & 171 & Tinggi & 90.95 & 22.34 \\
\hline & & SP & $\mathrm{P}$ & 138 & 73.40 & Sedang & 179 & Tinggi & 95.21 & 21.81 \\
\hline & & FA & $\mathrm{L}$ & 129 & 68.61 & Rendah & 160 & Sedang & 85.10 & 16.49 \\
\hline & & YR & $\mathrm{L}$ & 132 & 70.21 & Rendah & 175 & Tinggi & 93.08 & 22.87 \\
\hline & & RA & $\mathrm{P}$ & 138 & 73.40 & Sedang & 180 & Tinggi & 95.74 & 22.35 \\
\hline \multirow{10}{*}{$\begin{array}{l}\overline{0} \\
\stackrel{\Xi}{0} \\
\stackrel{0}{0}\end{array}$} & \multirow{10}{*}{188} & MR & $\mathrm{L}$ & 137 & 72.87 & Sedang & 140 & Rendah & 74.46 & 1.59 \\
\hline & & MA & $\mathrm{L}$ & 136 & 72.34 & Rendah & 120 & Rendah & 63.82 & -8.52 \\
\hline & & NA & $\mathrm{P}$ & 137 & 72.87 & Sedang & 141 & Rendah & 75 & 2.13 \\
\hline & & FS & $\mathrm{L}$ & 137 & 72.87 & Sedang & 138 & Sedang & 73.40 & 0.53 \\
\hline & & GF & $\mathrm{P}$ & 136 & 72.34 & Rendah & 130 & Rendah & 69.14 & -3.2 \\
\hline & & AA & $\mathrm{P}$ & 135 & 71.80 & Rendah & 139 & Rendah & 73.96 & 2.16 \\
\hline & & LF & $\mathrm{L}$ & 138 & 73.40 & Sedang & 142 & Sedang & 75.53 & 2.13 \\
\hline & & $\mathrm{AF}$ & $\mathrm{P}$ & 138 & 73.40 & Sedang & 138 & Sedang & 73.40 & 0 \\
\hline & & RA & $\mathrm{P}$ & 138 & 73.40 & Sedang & 142 & Sedang & 75.53 & 2.13 \\
\hline & & $\mathrm{FE}$ & $\mathrm{L}$ & 132 & 70.21 & Rendah & 135 & Rendah & 71.80 & 1.59 \\
\hline
\end{tabular}

Tabel 2. Tabel Rata-Rata Capaian Skor

\begin{tabular}{ccccccc}
\hline $\begin{array}{c}\text { Skor } \\
\text { Rata-Rata }\end{array}$ & $\begin{array}{c}\text { Skor } \\
\text { Ideal }\end{array}$ & Pretest & $\%$ & Posttest & $\%$ & Peningkatan \\
\hline Eksperimen & 188 & 134.9 & 71.75 & 173 & 92.02 & 20.27 \\
& & & & & & \\
Kontrol & 188 & 136.4 & 72.55 & 136.5 & 72.60 & 0.05 \\
\hline
\end{tabular}


Tabel 3. Tabel Capaian Toleransi per Aspek Kelompok Eksperimen

\begin{tabular}{|c|c|c|c|c|c|c|c|c|}
\hline \multirow[t]{3}{*}{ No } & \multirow[t]{3}{*}{ Nama } & \multirow[t]{3}{*}{ JK } & \multirow{2}{*}{\multicolumn{2}{|c|}{$\begin{array}{l}\text { Aspek toleransi } \\
\text { Aspek } 1\end{array}$}} & Ket & \multirow{2}{*}{\multicolumn{2}{|c|}{$\begin{array}{l}\text { Aspek toleransi } \\
\text { Aspek } 2\end{array}$}} & \multirow[t]{3}{*}{ Ket } \\
\hline & & & & & & & & \\
\hline & & & Pretest & posttest & & Pretest & Posttest & \\
\hline 1 & AN & $\mathrm{L}$ & 68 & 92 & Meningkat & 68 & 87 & Meningkat \\
\hline 2 & $\mathrm{AB}$ & $\mathrm{L}$ & 69 & 77 & Meningkat & 66 & 80 & Meningkat \\
\hline 3 & $\mathrm{AJ}$ & $\mathrm{P}$ & 69 & 92 & Meningkat & 68 & 82 & Meningkat \\
\hline 4 & JL & $\mathrm{L}$ & 64 & 73 & Meningkat & 90 & 86 & Meningkat \\
\hline 5 & AA & $P$ & 69 & 89 & Meningkat & 68 & 90 & Meningkat \\
\hline 6 & $\mathrm{MD}$ & $\mathrm{L}$ & 58 & 87 & Meningkat & 71 & 84 & Meningkat \\
\hline 7 & SP & $\mathrm{P}$ & 60 & 91 & Meningkat & 78 & 88 & Meningkat \\
\hline 8 & FA & $\mathrm{L}$ & 65 & 80 & Meningkat & 64 & 80 & Meningkat \\
\hline 9 & YR & $\mathrm{L}$ & 68 & 89 & Meningkat & 64 & 86 & Meningkat \\
\hline 10 & RA & $\mathrm{P}$ & 59 & 79 & Meningkat & 90 & 90 & Meningkat \\
\hline \multicolumn{2}{|c|}{$\begin{array}{l}\text { Rata-Rata } \\
\text { Skor }\end{array}$} & & 65.6 & 85.6 & Meningkat & 70.8 & 84.8 & Meningkat \\
\hline
\end{tabular}

Tabel 4. Tabel Capaian Toleransi per Aspek Kelompok Kontrol

\begin{tabular}{ccccccccc}
\hline No & Nama & JK & \multicolumn{2}{c}{$\begin{array}{c}\text { Aspek toleransi } \\
\text { Aspek 1 }\end{array}$} & Ket & \multicolumn{2}{c}{$\begin{array}{c}\text { Aspek toleransi } \\
\text { Aspek 2 }\end{array}$} & Ket \\
& \multicolumn{3}{c}{$\begin{array}{c}\text { Pretest } \\
\text { posttest }\end{array}$} & & Pretest & Posttest & \\
\hline 1 & MR & L & 69 & 68 & Meningkat & 61 & 79 & Meningkat \\
2 & MH & L & 68 & 68 & Tetap & 59 & 61 & Meningkat \\
3 & NA & P & 70 & 67 & Menurun & 70 & 69 & Menurun \\
4 & FS & L & 70 & 67 & Menurun & 72 & 66 & Menurun \\
5 & GF & P & 69 & 67 & Meningkat & 66 & 64 & Menurun \\
6 & AA & P & 71 & 67 & Menurun & 72 & 66 & Menurun \\
7 & LF & L & 60 & 65 & Meningkat & 74 & 68 & Menurun \\
8 & AF & P & 71 & 67 & Menurun & 72 & 66 & Menurun \\
9 & RA & P & 70 & 68 & Menurun & 70 & 72 & Meningkat \\
10 & FE & L & 65 & 67 & Meningkat & 71 & 64 & Menurun \\
\multicolumn{2}{c}{ Rata-Rata } & & 68.3 & 67.1 & Menurun & 68.7 & 67.5 & Menurun \\
\multicolumn{2}{c}{ Skor } & & & & & & \\
\hline
\end{tabular}




\section{Lampiran}

\section{Rencana Pemberian Layanan Bimbingan Kelompok dengan Teknik Role playing Pertemuan $\mathrm{Ke}-\mathrm{I}$}

1. Komponen
a. Sasaran
: 10 Orang siswa kelas X SMKN 26 Jakarta
b. Tempat
: Ruang BK SMKN 26 Jakarta
c. Waktu pelaksanaan : Juli 2017
d. Alokasi waktu : 60-90 Menit
e. Penyelenggara : peneliti
f. Pihak yang terlibat : peneliti, siswa, observer

2. Aspek Perkembangan

Kematangan hubungan dengan teman sebaya

3. Standar kompetensi

Mempelajari cara-cara membina kerjasama dan toleransi dalam pergaulan dengan teman sebaya.

4. Indikator
a. Siswa memahami makna toleransi
b. Siswa menyadari manfaat memiliki toleransi
c. Siswa memahami bentuk-bentuk perilaku toleransi dalam kehidupan
d. Siswa memiliki kesadaran untuk bertoleransi terhadap perbedaan

5. Topik Bimbingan : Tidak memaksakan pendapat diri sendiri terhadap orang lain

6. Tujuan
a. Siswa mampu mengetahui makna dari perilaku tidak memaksakan pendapat diri sendiri terhadap orang lain
b. Siswa mampu mengidentifikasi ciri-ciri dari perilaku tidak memaksakan pendapat diri sendiri terhadap orang lain
c. Siswa mampu mengetahui manfaat dan dampak dari perilaku Tidak memaksakan pendapat diri sendiri terhadap orang lain
d. Siswa menyadari pentingnya memiliki perilaku yang Tidak memaksakan pendapat diri sendiri terhadap orang lain

7. Bidang bimbingan : Pribadi dan sosial 
8. Fungsi layanan : Pemahaman dan pengembangan

9. Teknik yang digunakan : Role playing dalam format "memeragakan caranya".

10. Media/sumber : Perlengkapan Role Play (disesuaikan dengan alat yang tersedia)

11. Langkah kegiatan layanan

\begin{tabular}{|c|c|}
\hline Beginning stage & $\begin{array}{l}\text { Alokasi } \\
\text { waktu }\end{array}$ \\
\hline 1. Peneliti menerima kehadiran anggota kelompok dan memperkenalkan diri & 3 ' \\
\hline 2. Peneliti memimpin doa & 2 ' \\
\hline 3. Menjelaskan tujuan dilakukan kegiatan bimbingan kelompok & 5 ' \\
\hline $\begin{array}{l}\text { 4. Mendiskusikan secara garis besar kegiatan bimbingan kelompok yang akan } \\
\text { dilaksanakan }\end{array}$ & 5 \\
\hline 5. mendiskusikan pengertian dan asas-asas bimbingan kelompok & 5 , \\
\hline 6. Mendiskusikan peraturan yang harus ditaati selama kegiatan berlangsung & 5 \\
\hline $\begin{array}{l}\text { 7. Mendiskusikan secara garis besar teknik yang akan digunakan selama kegiatan } \\
\text { bimbingan kelompok, yaitu teknik role playing }\end{array}$ & $10^{\prime}$ \\
\hline 8. Mendiskusikan kesepakatan waktu kegiatan bimbingan kelompok & 5 , \\
\hline $\begin{array}{l}\text { 9. Peneliti bersama-sama anggota kelompok melakukan ice breaking untuk lebih } \\
\text { mengenal satu sama lain dan mencairkan suasana. Ice breaking yang digunakan } \\
\text { yaitu "rangkai kata" }\end{array}$ & $15^{\prime}$ \\
\hline $\begin{array}{l}\text { 10. Peneliti menjelaskan topik pertama yang akan dibahas yaitu "tidak memaksakan } \\
\text { pendapat diri sendiri terhadap orang lain" }\end{array}$ & 5 ' \\
\hline \multirow[t]{2}{*}{ 11. Peneliti menanyakan kesiapan anggota kelompok untuk melanjutkan kegiatan } & 5 \\
\hline & $\begin{array}{c}\text { Total: } \\
65 \\
\text { Menit }\end{array}$ \\
\hline
\end{tabular}




\section{Working stage}

1. Peneliti melaksanakan rencana pemberian layanan dengan terlebih dahulu membuat beberapa permasalahan yang akan dipentaskan terkait dengan topik yang sedang dibahas.

Cerita 1: ketika sedang berdiskusi dikelas membahas rencana kegiatan pentas seni. A dan B memiliki pendapat dan ide yang berbeda tentang konsep pentas seni tersebut. A dan B memiliki alasan dan argument yang sangat kuat. Namun, hanya satu ide yang diterima oleh rekan yang lain, yaitu ide dari A karena beberapa alasan dan pertimbangan. Bagaimana sikap A dalam menghadapi situasi tersebut jika A memiliki sikap toleransi? Bagaimana sikap A dalam menghadapi situasi tersebut jika A tidak memiliki sikap toleransi?

Cerita 2: A dan B merupakan sahabat dekat. A sedang memiliki permasalahan dengan orangtua nya yang otoiter dan overprotektif. Meski demikian A sangat menyayangi dan patuh terhadap orangtua nya. Di sisi lain A merupakan anak satu-satunya. A merupakan harapan orangtuanya. A memiliki sifat yang pendiam dan cenderung tertutup. A menceritakan masalahnya tersebut kepada B. A memberi saran kepada B untuk berontak dan sesekali berperilaku nakal agar orangtua nya paham. Namun, A kurang bisa menerima saran B tersebut. B merasa bahwa saran yang diberikannya benar. Karena A tidak menyetujui saran tersebut B pun menganggap A pecundang dan menjauhinya. Bagaimana sikap B dalam menghadapi situasi tersebut jika B memiliki sikap toleransi? Bagaimana sikap B dalam menghadapi situasi tersebut jika B tidak memiliki sikap toleransi?

2. Peneliti membagi anggota menjadi 2 kelompok. Peneliti memilih anggota yang akan menjadi pemain utama, pembantu, dan pengamat dari setiap kelompok.

3. Peneliti memberi waktu 5 hingga 10 menit kepada siswa untuk memahami peran dan karakter serta mengatur situasi yang akan dilaksanakan.

4. anggota mulai memainkan peranannya masing-masing.

5. Diskusi dan evaluasi kegiatan bermain peran yang sudah dilaksanakan

6. Memerankan kembali, kemudian diskusi dan evaluasi

7. Berbagi dan mengembangkan pengalaman yang didapatkan dari kegiatan bermain peran 


\section{Closing stage}

1. Peneliti mengemukakan bahwa kegiatan akan segera diakhiri 2

2. Peneliti dan anggota kelompok mengemukakan kesan dan hasil-hasil kegia$\tan$

3. Peneliti bersama anggota kelompok mengemukakan pesan dan harapan

4. Peneliti bersama anggota kelompok akan membahas mengenai pertemuan selanjutnya.

Total: 